\title{
ARRIVALS OF FOREIGN TOURISTS TO POLAND
}

\author{
ANNA TURCZAK \\ University of Szczecin, Faculty of Management and Economics of Services, POLAND \\ e-mail: anna.turczak@usz.edu.pl \\ RECEIVED \\ 10 December 2018 \\ ACCEPTED \\ 28 December 2018 \\ JEL \\ CLASSIFICATION \\ $\mathrm{C} 65, \mathrm{Z} 31, \mathrm{Z} 32$ \\ KEYWORDS inbound tourism, expenditure, foreign tourist, direct impact, total impact \\ \begin{tabular}{l|l} 
ABSTRACT & Tourism is one of the world's largest economic sectors. It creates jobs, drives exports, and generates
\end{tabular} \\ prosperity across the world. As well as its direct economic impact, the industry has significant indirect and \\ induced impacts. In 2017 , the sector accounted for $10.4 \%$ of global GDP and 313 million jobs, or $9.9 \%$ of total \\ employment. Tourism is important to significant extent for numerous fields of social and economic life in Poland. \\ The aim of the article is to examine the impacts of two factors influencing the total amount of money spent by \\ foreign tourists visiting Poland. The first factor is the number of trips to Poland, and the second one - the mean \\ spending per trip.
}

\section{Introduction}

\section{Introduction}

The term "tourism" - in accordance with the regulation No. 692/2011 of the European Parliament and the Council - means the activities of visitors taking a trip to a main destination outside their usual environment, for 
less than a year, for any main purpose, including business, leisure or other personal purpose other than to be employed by a resident entity in the place visited. The "tourists" term does not mean the same as the 'visitors' term. The 'visitors' category refers to tourists (i.e. visitors who occupied accommodation establishments within the given location for at least one night) and same-day visitors (not accommodated).

\section{The economic impact of tourism}

Tourism contributes to Gross Domestic Product (GDP) and employment in many ways. The total contribution of the industry consists of the direct, indirect and induced impacts on the economy. The indirect impact includes the GDP and jobs supported by:

a) tourism investment spending (such as the purchase of new aircraft and construction of new hotels);

b) government spending on tourism marketing and promotion, aviation, administration, security services, sanitation services, etc.;

c) domestic purchases of goods and services including - for example - purchases of food and cleaning services by hotels, of fuel and catering services by airlines, and IT services by travel agents (Travel \& tourism..., 2018).

The induced contribution measures the GDP and jobs supported by the spending of those who are directly or indirectly employed by the tourism industry. The data concerning Poland, the European Union and the whole world are given in Table 1.

Table 1. Tourism's absolute and relative contribution in 2017

\begin{tabular}{|c|c|c|}
\hline Specification & Absolute size & $\begin{array}{c}\text { Relative size } \\
(\%)\end{array}$ \\
\hline 1 & 2 & 3 \\
\hline \multicolumn{3}{|c|}{ Total contribution to GDP } \\
\hline Poland & 23.9 bn USD $\approx 89.9$ bn PLN & 4.5 \\
\hline European Union average & 63.8 bn USD & 10.3 \\
\hline World average & 62.9 bn USD & 10.4 \\
\hline \multicolumn{3}{|c|}{ Direct contribution to GDP } \\
\hline Poland & $10.2 \mathrm{bn}$ USD $\approx 38.2 \mathrm{bn}$ PLN & 1.9 \\
\hline European Union average & 23.8 bn USD & 3.9 \\
\hline World average & 21.5 bn USD & 3.2 \\
\hline \multicolumn{3}{|c|}{ Total contribution to employment } \\
\hline Poland & 738.2 thous. jobs & 4.5 \\
\hline European Union average & 975.2 thous. jobs & 11.7 \\
\hline World average & $2,341.0$ thous. jobs & 9.9 \\
\hline \multicolumn{3}{|c|}{ Direct contribution to employment } \\
\hline Poland & 332.0 thous. jobs & 2.0 \\
\hline European Union average & 424.6 thous. jobs & 5.1 \\
\hline World average & 937.5 thous. jobs & 3.8 \\
\hline \multicolumn{3}{|c|}{ Contribution to exports } \\
\hline Poland & 13.0 bn USD $\approx 49.1$ bn PLN & 4.6 \\
\hline European Union average & 16.2 bn USD & 5.8 \\
\hline World average & 8.1 bn USD & 6.5 \\
\hline
\end{tabular}




\begin{tabular}{lcc}
\hline \multicolumn{1}{c}{ Contribution to capital investment } & 3 \\
\hline Poland & 2.8 bn USD $\approx 10.4$ bn PLN & 3.0 \\
European Union average & 6.3 bn USD & 5.1 \\
World average & 4.8 bn USD & 4.5 \\
\hline
\end{tabular}

Source: own compilation based on (Travel \& tourism..., 2018).

In 2017, the world total contribution of tourism to GDP was 62.9 bn USD per country (with direct contribution of 21.5 bn USD). The sector supported on average 2,341.0 thous. jobs (937.5 thous. directly). It should also be mentioned that tourism attracted investment of 4.8 bn USD/country and generated on average 8.1 bn USD in exports.

As shown by the data in table 1, the relative size of the sector in the Polish economy is considerably smaller than in the average European Union economy and smaller than in the average economy in the world.

\section{Inbound tourism in Poland - key information}

Poland has a diversified natural environment. The Baltic Sea in the north and the Sudetes and Carpathian mountain ranges in the south form natural borders of the country. The best recreational destinations include (Turczak, 2018):

a) Masurian lakes (the Masurian Lake District in north-eastern Poland counts around 2,000 lakes on an area of about $\left.52,000 \mathrm{~km}^{2}\right)$;

b) Baltic coast (there are dozens of sea resorts on the coast of Baltic Sea; the coast stretches $770 \mathrm{~km}$; a distinctive part of the coast is the Hel Peninsula, which is $35 \mathrm{~km}$ long);

c) Tatra mountains (this is the highest mountain range of Carpathians; the most famous resort for skiing and hiking in the Tatras is Zakopane);

d) Sudetes (there are lots of tourist resort - e.g. Karpacz, Szklarska Poręba - for skiing and hiking in the Karkonosze mountains, which is a part of the Sudetes mountain range);

e) Białowieża Forest (Białowieża National Park is the last fragment of the primeval forest which once stretched across the European plain; it is home to the world's largest population of European bison and many other endangered species; the oldest oaks in this forest are 650 years old).

Since 2014, the Central Statistical Office has conducted research providing information on the arrivals of foreigners to Poland. There have been also collected data on expenditures of foreigners related to travel. According to that collection of data, there were 83.8 million foreigners, including 18.3 million tourists and 65.5 million same-day visitors, who came to Poland in 2017 (13.7\%, 14.1\% and 13.3\% more than in 2014, respectively). Almost every second arriving foreigner was in the age group of 35-54 (in 2017, 48.2\%). People aged 25-34 also constituted a large group (18.8\%).

Tourists travel for variety of different reasons. The purposes of international tourism can be, among others (Inkson, Minnaert, 2012, pp. 21-22): leisure, recreation, and holidays; visiting friends and relatives; education and training; business and professional reasons; health treatment; religion and pilgrimages; shopping. 


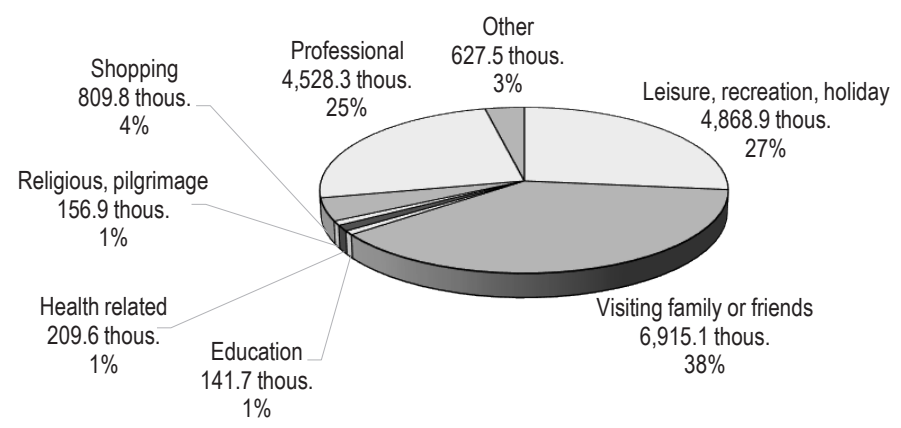

Figure 1. Trips of tourists to Poland by main purpose in 2017

Source: own compilation based on Tourism in 2017 (2018).

In 2017, expenditure of foreigners visiting Poland ${ }^{1}$ amounted to 56.7 bn PLN, which was $31.6 \%$ more than in 2014, of which tourists -32.8 bn PLN (42.6\% more than in 2014) and same-day visitors - 23.9 bn PLN (18.9\% more than in 2014).

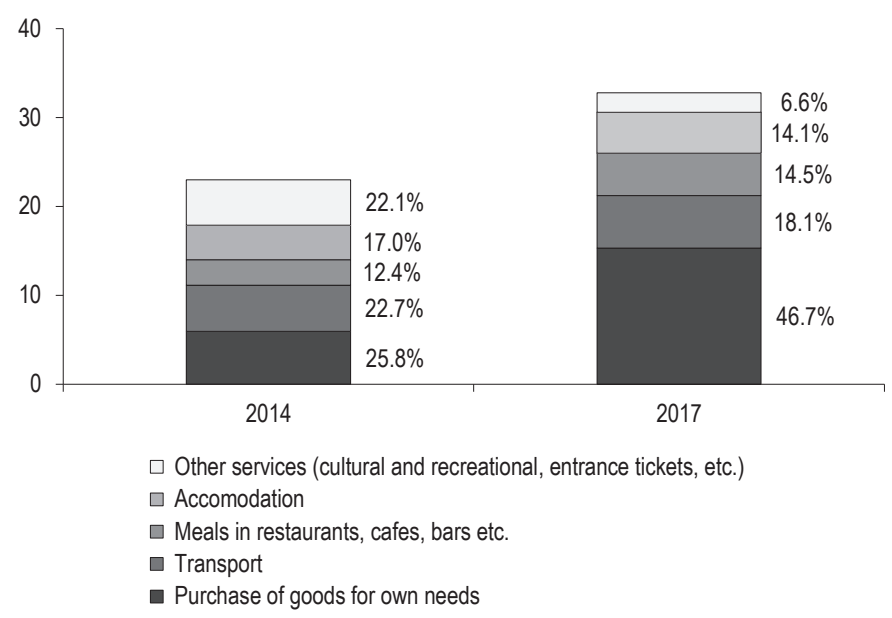

Figulre 2. Expenses of tourists connected with travel to Poland in 2014 and 2017 (bn PLN)

Source: own compilation based on Tourism in 2014 (2015) and Tourism in 2017 (2018).

${ }^{1}$ Tourism expenditure covers expenditure (monetary) for the purchase of consumer goods and services (including durable consumer goods and high value objects) incurred before and during the trip directly by tourists as well as financed or reimbursed by the employer, other persons or institutions. They include all tourism expenditure even if the services were booked and paid before the trip or if the actual payment occurred after the trip. Tourism expenditure does not include expenditure on the purchase of goods for resale. 


\section{Methoddology used}

The objective of causal analysis is to determine how various factors affect a given variable (Szczecińska, 2007). Therefore, causal analysis can answer the question of whether a particular factor causes an increase or a decrease of the studied variable, and enables us to assess how big the impact of this factor is (Turczak, 2016).

Expenditure of tourists arriving from abroad to Poland might be calculated by multiplication of the number of foreign tourists ${ }^{2}$ visiting Poland and the average spending per trip. The following notation has been adopted for the purpose of this article:

$M_{17}\left(M_{14}\right) \quad$ - expenditure in 2017 (in 2014),

$M_{17} \div M_{14} \quad$ - the nominal index referring to expenditure (current prices),

$i_{17 / 14} \quad$ - price index of goods and services $(2014=1)$,

$\frac{M_{17}}{i_{17 / 14}} \div M_{14} \quad$ - the real index referring to expenditure (2014 prices),

$n_{17}\left(n_{14}\right) \quad$ - the number of tourists in 2017 (in 2014),

$n_{17} \div n_{14} \quad$ - the index referring to the number of tourists,

$m_{17}\left(m_{14}\right) \quad$ - expenditure per trip in 2017 (in 2014),

$m_{17} \div m_{14} \quad$ - the nominal index referring to expenditure per trip,

$\frac{m_{17}}{i_{17 / 14}} \div m_{14} \quad-\quad$ the real index referring to expenditure per trip (2014 prices).

Since $\frac{M_{17}}{i_{17 / 14}}=n_{17} \times \frac{m_{17}}{i_{17 / 14}}$ and $M_{14}=n_{14} \times m_{14}$, when dividing $\frac{M_{17}}{i_{17 / 14}}$ by $M_{14}$, the result is:

$$
\frac{\frac{M_{17}}{i_{17 / 14}}}{M_{14}}=\frac{n_{17} \times \frac{m_{17}}{i_{17 / 14}}}{n_{14} \times m_{14}} .
$$

The same can be shown in a different way, namely:

$$
\left(\frac{M_{17}}{i_{17 / 14}} \div M_{14}\right)=\left(n_{17} \div n_{14}\right) \cdot\left(\frac{m_{17}}{i_{17 / 14}} \div m_{14}\right) \text {. }
$$

Taking the common logarithms of both sides of the equation, the following expression can be obtained:

$$
\log \left(\frac{M_{17}}{i_{17 / 14}} \div M_{14}\right)=\log \left[\left(n_{17} \div n_{14}\right) \times\left(\frac{m_{17}}{i_{17 / 14}} \div m_{14}\right)\right]
$$

2 The term 'number of tourists' shall stand for the number of arrivals for the purpose of this article. That means if one person arrived to Poland more than once during the analysed year, they will be counted repeatedly, i.e. in accordance with the number of arrivals (UNWTO Tourism..., 2018). 
Then, using the logarithm property stipulating that the logarithm of a product of some numbers is equal to the sum of the logarithms of these numbers (Turczak, 2017), the equation presented below can be derived:

$$
\log \left(\frac{M_{17}}{i_{17 / 14}} \div M_{14}\right)=\log \left(n_{17} \div n_{14}\right)+\log \left(\frac{m_{17}}{i_{17 / 14}} \div m_{14}\right) .
$$
expression:

The next step is to divide both sides of the equation by the term $\log \left(\frac{M_{17}}{i_{17 / 14}} \div M_{14}\right)$. This results in the
insion:

$$
1=\frac{\log \left(n_{17} \div n_{14}\right)}{\log \left(\frac{M_{17}}{i_{17 / 14}} \div M_{14}\right)}+\frac{\log \left(\frac{m_{17}}{i_{17 / 14}} \div m_{14}\right)}{\log \left(\frac{M_{17}}{i_{17 / 14}} \div M_{14}\right)}
$$

where:

$$
\begin{aligned}
& \frac{\log \left(n_{17} \div n_{14}\right)}{\log \left(\frac{M_{17}}{i_{17 / 14}} \div M_{14}\right)}-\text { the impact of the change of } n \text { on the change of } M \\
& \frac{\log \left(\frac{m_{17}}{i_{17 / 14}} \div m_{14}\right)}{\log \left(\frac{M_{17}}{i_{17 / 14}} \div M_{14}\right)}-\text { the impact of the change of } m \text { on the change of } M
\end{aligned}
$$

The final step is to multiply both sides of the equation by the absolute change (i.e. the absolute increase or the absolute decrease) calculated for the variable M. Finally:

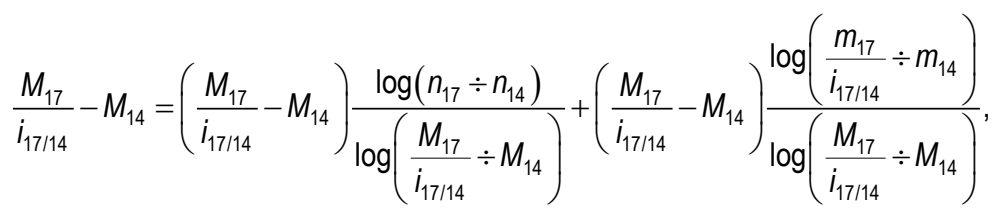

where:

$$
\begin{aligned}
& \frac{M_{17}}{i_{17 / 14}}-M_{14}-\text { the absolute change of } M, \\
& \left(\frac{M_{17}}{i_{17 / 14}}-M_{14}\right) \frac{\log \left(n_{17} \div n_{14}\right)}{\log \left(\frac{M_{17}}{i_{17 / 14}} \div M_{14}\right)}-\text { the change of } M \text { caused by the change of } n \\
& \left(\frac{M_{17}}{i_{17 / 14}}-M_{14}\right) \frac{\log \left(\frac{m_{17}}{i_{17 / 14}} \div m_{14}\right)}{\log \left(\frac{M_{17}}{i_{17 / 14}} \div M_{14}\right)}-\text { the change of } M \text { caused by the change of } m .
\end{aligned}
$$




\section{Analysis of tourism expenditure}

The first task is to compare expenditure incurred in connection with foreign tourists' trips to Poland in 2017 with the analogous value in 2014. Table 2 contains the relevant data.

Table 2. The index referring to expenditure

\begin{tabular}{|c|c|c|c|c|}
\hline \multirow{2}{*}{$\begin{array}{l}\text { Country of permanent } \\
\text { residence }\end{array}$} & \multicolumn{2}{|c|}{$\begin{array}{l}\text { Expenditure } \\
\text { (million PLN) }\end{array}$} & \multirow{2}{*}{$\begin{array}{c}\text { Nominal index referring } \\
\text { to expenditure }\end{array}$} & \multirow{2}{*}{$\begin{array}{c}\text { Real index referring } \\
\text { to expenditure }\end{array}$} \\
\hline & 2017 & 2014 & & \\
\hline Netherlands & 852.4 & 180.1 & 4.732 & 4.715 \\
\hline Latvia & 603.6 & 157.9 & 3.822 & 3.808 \\
\hline Spain & 729.8 & 313.8 & 2.325 & 2.317 \\
\hline Romania & 208.4 & 97.7 & 2.132 & 2.125 \\
\hline China & $1,044.4$ & 552.0 & 1.892 & 1.885 \\
\hline Italy & 946.8 & 519.6 & 1.822 & 1.815 \\
\hline Lithuania & 747.5 & 424.2 & 1.762 & 1.756 \\
\hline Ukraine & $1,434.6$ & 837.1 & 1.714 & 1.708 \\
\hline Other countries together & $5,778.9$ & $3,536.5$ & 1.634 & 1.628 \\
\hline Sweden & 602.6 & 378.4 & 1.593 & 1.587 \\
\hline Czech Republic & 263.7 & 171.2 & 1.540 & 1.534 \\
\hline Germany & $10,003.1$ & $6,619.4$ & 1.511 & 1.506 \\
\hline France & 852.5 & 621.9 & 1.371 & 1.366 \\
\hline Hungary & 319.6 & 254.6 & 1.255 & 1.251 \\
\hline Slovakia & 166.0 & 135.0 & 1.230 & 1.225 \\
\hline Austria & 702.7 & 606.4 & 1.159 & 1.155 \\
\hline Norway & 724.8 & 641.7 & 1.130 & 1.125 \\
\hline United States & $2,695.4$ & $2,407.8$ & 1.119 & 1.115 \\
\hline Ireland & 404.7 & 377.9 & 1.071 & 1.067 \\
\hline Belarus & 754.1 & 721.2 & 1.046 & 1.042 \\
\hline United Kingdom & $1,589.3$ & $1,825.2$ & 0.871 & 0.868 \\
\hline Russia & $1,066.1$ & $1,264.8$ & 0.843 & 0.840 \\
\hline Switzerland & 276.9 & 331.1 & 0.836 & 0.833 \\
\hline
\end{tabular}

Source: own computation based on Tourism in 2014 (2015); Tourism in 2017 (2018); Concise... (2018).

The top place was taken by the Netherlands (the greatest increase, i.e. $373.2 \%$ in nominal terms and $371.5 \%$ in real terms). The last place was occupied by Switzerland (the largest decrease, $16.4 \%$ and $16.7 \%$, respectively).

\section{Analysis of the number of foreign tourists}

The next task carried out is to compare the number of foreign tourists in 2017 in relation to the number in 2014. All the data needed have been presented in Table 3.

The first position belonged to the Netherlands (an increase of $261.8 \%$ ). In turn, the lowest index number concerned the United Kingdom. 
Table 3. The index referring to the number of tourists

\begin{tabular}{|c|c|c|c|}
\hline \multirow[t]{2}{*}{ Country of permanent residence } & \multicolumn{2}{|c|}{$\begin{array}{l}\text { Number of persons } \\
\text { (thousand) }\end{array}$} & \multirow{2}{*}{$\begin{array}{c}\text { Index referring to the number } \\
\text { of tourists } \\
2017 / 2014 \\
\end{array}$} \\
\hline & 2017 & 2014 & \\
\hline Netherlands & 460.6 & 127.3 & 3.618 \\
\hline Latvia & 368.0 & 131.4 & 2.801 \\
\hline Spain & 374.9 & 143.4 & 2.614 \\
\hline Sweden & 323.8 & 208.6 & 1.552 \\
\hline Other countries together & $1,919.5$ & $1,263.7$ & 1.519 \\
\hline Norway & 445.8 & 298.2 & 1.495 \\
\hline Italy & 526.1 & 357.4 & 1.472 \\
\hline Ukraine & $1,359.8$ & $1,072.8$ & 1.268 \\
\hline Romania & 142.8 & 113.6 & 1.257 \\
\hline Slovakia & 188.4 & 158.2 & 1.191 \\
\hline Czech Republic & 307.2 & 265.5 & 1.157 \\
\hline Germany & $6,503.9$ & $5,743.1$ & 1.132 \\
\hline Lithuania & 677.4 & 605.2 & 1.119 \\
\hline France & 518.2 & 514.9 & 1.006 \\
\hline Belarus & 763.3 & 811.5 & 0.941 \\
\hline Ireland & 220.4 & 234.6 & 0.939 \\
\hline China & 144.3 & 159.4 & 0.905 \\
\hline Russia & 875.4 & $1,003.1$ & 0.873 \\
\hline Switzerland & 166.8 & 203.3 & 0.820 \\
\hline Austria & 388.0 & 484.4 & 0.801 \\
\hline United States & 495.6 & 645.0 & 0.768 \\
\hline Hungary & 236.9 & 316.0 & 0.750 \\
\hline United Kingdom & 850.7 & $1,138.8$ & 0.747 \\
\hline
\end{tabular}

Source: own computation based on Tourism in 2014 (2015) and Tourism in 2017 (2018).

\section{Analysis of tourism expenditure per visitor}

The third task is to compare expenditure incurred in connection with foreign tourists' trips to Poland in proportion to the number of persons visiting this country. The necessary data have been given in Table 4 .

Table 4. The index referring to average expenditure per tourist

\begin{tabular}{lcccc}
\hline \multirow{2}{*}{$\begin{array}{c}\text { Country of permanent } \\
\text { residence }\end{array}$} & \multicolumn{2}{c}{$\begin{array}{c}\text { Average expenditure per tourist } \\
(\mathrm{PLN})\end{array}$} & $\begin{array}{c}\text { Nominal index referring } \\
\text { to expenditure per tourist }\end{array}$ & $\begin{array}{c}\text { Real index referring } \\
\text { to expenditure per tourist }\end{array}$ \\
\cline { 2 - 5 } & 2017 & 2014 & $2017 / 2014$ & $2017 / 2014$ \\
\hline China & 2 & 3 & 4 & 5 \\
Romania & 7,235 & 3,463 & 2.089 & 2.082 \\
Hungary & 1,460 & 861 & 1.696 & 1.689 \\
Lithuania & 1,349 & 806 & 1.674 & 1.668 \\
United States & 1,104 & 701 & 1.575 & 1.569 \\
Austria & 5,438 & 3,733 & 1.457 & 1.451 \\
Latvia & 1,811 & 1,252 & 1.446 & 1.441 \\
France & 1,640 & 1,202 & 1.364 & 1.359 \\
\hline
\end{tabular}




\begin{tabular}{lrrcc}
\hline \multicolumn{1}{c}{1} & \multicolumn{1}{c}{3} & \multicolumn{1}{c}{ 3 } & \multicolumn{1}{c}{5} \\
\hline Ukraine & 1,055 & 780 & 1.353 & 1.348 \\
Germany & 1,538 & 1,153 & 1.334 & 1.329 \\
Czech Republic & 858 & 645 & 1.330 & 1.325 \\
Netherlands & 1,850 & 1,415 & 1.307 & 1.303 \\
Italy & 1,800 & 1,454 & 1.238 & 1.233 \\
United Kingdom & 1,868 & 1,603 & 1.165 & 1.161 \\
Ireland & 1,836 & 1,611 & 1.140 & 1.135 \\
Belarus & 988 & 889 & 1.111 & 1.107 \\
Other countries together & 3,011 & 2,799 & 1.076 & 1.072 \\
Slovakia & 881 & 854 & 1.032 & 1.028 \\
Sweden & 1,861 & 1,814 & 1.026 & 1.022 \\
Switzerland & 1,660 & 1,629 & 1.019 & 1.015 \\
Russia & 1,218 & 1,261 & 0.966 & 0.962 \\
Spain & 1,947 & 2,188 & 0.890 & 0.887 \\
Norway & 1,626 & 2,152 & 0.756 & 0.753 \\
\hline
\end{tabular}

Source: own computation based on Tourism in 2014 (2015); Tourism in 2017 (2018); Concise... (2018).

The top place was taken by China (the greatest increase, i.e. $108.9 \%$ in nominal terms and $108.2 \%$ in real terms). The last place was occupied by Norway (the largest decrease, $24.4 \%$ and $24.7 \%$, respectively).

\section{Results of the causal analysis}

In the last part of this research the remaining stages of the logarithmic method will be performed. The results are shown in Table 5.

Table 5. The index equality and the equation of impact effects (in real terms)

\begin{tabular}{lcc}
\hline \multicolumn{1}{c}{ Country of permanent residence } & The index equality & $\begin{array}{c}\text { The equation of impact effects } \\
\text { (results in million PLN) }\end{array}$ \\
\hline \multicolumn{1}{c}{1} & 2 & 3 \\
\hline Netherlands & $4.715=3.618 \times 1.303$ & $(+669.1)=(+554.9)+(+114.1)$ \\
Latvia & $3.808=2.801 \times 1.359$ & $(+443.5)=(+341.5)+(+101.8)$ \\
Spain & $2.317=2.614 \times 0.887$ & $(+413.3)=(+472.7)+(-59.2)$ \\
Romania & $2.125=1.257 \times 1.689$ & $(+109.9)=(+33.4)+(+76.5)$ \\
China & $1.885=0.905 \times 2.082$ & $(+488.6)=(-76.7)+(+565.0)$ \\
Italy & $1.815=1.472 \times 1.233$ & $(+423.7)=(+274.7)+(+149.1)$ \\
Lithuania & $1.756=1.119 \times 1.569$ & $(+320.6)=(+64.2)+(+256.6)$ \\
Ukraine & $1.708=1.268 \times 1.348$ & $(+592.3)=(+262.4)+(+330.2)$ \\
Other countries together & $1.628=1.519 \times 1.072$ & $(+2,221.2)=(+1,905.0)+(+316.2)$ \\
Sweden & $1.587=1.552 \times 1.022$ & $(+222.0)=(+211.4)+(+10.5)$ \\
Czech Republic & $1.534=1.157 \times 1.325$ & $(+91.5)=(+31.2)+(+60.2)$ \\
Germany & $1.506=1.132 \times 1.329$ & $(+3,347.0)=(+1,017.5)+(+2,326.5)$ \\
France & $1.366=1.006 \times 1.357$ & $(+227.4)=(+4.7)+(+222.7)$ \\
Hungary & $1.251=0.750 \times 1.668$ & $(+63.8)=(-82.2)+(+145.9)$ \\
Slovakia & $1.225=1.191 \times 1.028$ & $(+30.4)=(+26.2)+(+4.1)$ \\
Austria & $1.155=0.801 \times 1.441$ & $(+93.7)=(-144.7)+(+238.3)$ \\
Norway & $1.125=1.495 \times 0.753$ & $(+80.5)=(+273.9)+(-193.4)$ \\
\hline
\end{tabular}




\begin{tabular}{lcc}
\hline & 2 & 3 \\
\hline United States & $1.115=0.768 \times 1.451$ & $(+277.7)=(-670.3)+(+947.8)$ \\
Ireland & $1.067=0.939 \times 1.135$ & $(+25.3)=(-24.4)+(+49.6)$ \\
Belarus & $1.042=0.941 \times 1.107$ & $(+30.2)=(-45.1)+(+75.0)$ \\
United Kingdom & $0.868=0.747 \times 1.161$ & $(-241.7)=(-496.3)+(+254.1)$ \\
Russia & $0.840=0.873 \times 0.962$ & $(-202.6)=(-158.0)+(-44.5)$ \\
Switzerland & $0.833=0.820 \times 1.015$ & $(-55.2)=(-59.9)+(+4.6)$ \\
\hline
\end{tabular}

Source: own computation based on Tables 2-4.

As an example, the values obtained for Germany shall be interpreted. In 2017, German tourists arriving to Poland spent a total of 10,003.1 million PLN ${ }^{3}$ (in $2014-6,619.4$ million PLN). Had the average amount of money spent by 1 tourist from Germany been in 2017 at the level it was in 2014, the German tourists' expenditure would have been 1,017.5 million PLN ${ }^{4}$ higher in 2017 than in 2014, only due to the fact that more German citizens visited Poland in 2017 than in 2014 (6,503.9 thous. versus 5,743.1 thous.). Had the number of persons from Germany visiting Poland been in 2017 the same as in 2014, the German tourists' expenditure would have been 2,326.5 million PLN ${ }^{5}$ higher in 2017 than in 2014, which would have been a result solely of the greater average amount of money spent by Germans per one stay in Poland (1,538 PLN/trip ${ }^{6}$ against 1,153 PLN/trip).

\section{Conclusions}

Visitors are people taking a trip to a main destination outside their usual environment, for less than a year, for any main purpose (business, leisure or other personal purpose) other than to be employed by a resident entity in the place visited. Visitors are classified as tourists if their trip includes an overnight stay, and as same-day visitors (excursionists) otherwise.

Tourism affects destination areas in many ways. That is why it is so important to emphasise that the proper objectives of sustainable tourism are: to improve the quality of life of host communities, to provide a high quality experience for visitors, and - at the same time - to take care of the environment (Mill, Morrison, 2009, p. 61).

Tourism, which already supports one in every ten jobs on the planet, is a dynamic engine of employment opportunity. Over the past ten years, one in five of all jobs created across the world has been in this sector.

2017 was one of the strongest years of GDP growth in a decade with robust consumer spending worldwide. The global growth transferred again into tourism with the sector's direct growth of $4.6 \%$ outpacing the global economy for the seventh successive year.

Poland is one of the countries with constantly increasing number of visitors. In 2017 the number of tourist arrivals to this country amounted to 18.3 million. In 2017 in Poland, the entire contribution of tourism to GDP was 89.9 bn PLN (4.5\% of total GDP). The direct contribution to GDP was 38.2 bn PLN ( $1.9 \%$ of GDP). The whole contribution of tourism to employment accounted for $4.5 \%$ (738 thous. jobs), and the industry supported 332 thous.

\footnotetext{
${ }^{3}$ Current prices; 9,966.4 million PLN - 2014 prices.

42014 prices.

52014 prices.

${ }^{6}$ Current prices; 1,532 PLN/trip - 2014 prices.
} 
jobs directly (2.0\% of total employment). In 2017 in Poland, the amount of 10.4 bn PLN was invested in this sector (3.0\% of total investment) and tourism generated $4.6 \%$ of exports (i.e. 49.1 bn PLN).

\section{References}

Concise Statistical Yearbook of Poland (2018). Warsaw: Central Statistical Office.

Inkson, C., Minnaert, L. (2012). Tourism management. An introduction. USA: SAGE Publications.

Mill, R.Ch., Morrison, A.M. (2009). The tourism system. USA: Kendall Hunt Publishing Company.

Szczecińska, B. (2007). The application of the method of logarithm finding in the causal analysis of the financial results of enterprises of the food sector. Acta Scientiarum Polonorum Oeconomia, 6 (3), 99-104.

Tourism in 2014. (2015). Warsaw: Central Statistical Office.

Tourism in 2017. (2018). Warsaw: Central Statistical Office.

Travel \& tourism. Economic impact. Poland. (2018). London: World Travel \& Tourism Council.

Turczak, A. (2016). Differences in tourism receipts between Mexico and other countries. Estudios en Ciencias Sociales y Administrativas de la Universidad de Celaya, 6, 65-81.

Turczak, A. (2017). Characteristics of saving generated by the Baltic countries. Messenger of Armenian State University of Economics, 2, 80-92.

Turczak, A. (2018). Similarities and differences of travel and tourism in Poland and Finland - a quantitative approach. TAMKjournal, 12 January 2018, 1-6.

UNWTO Tourism Highlights: 2018 Edition. Retrieved from: www2.unwto.org/en.

Cite this article aS: Turczak, A. (2018). Arrivals of foreign tourists to Poland. European Journal of Service Management, 4(28/2), 511-521. DOI: 10.18276/ejsm.2018.28/2-62. 